\title{
Superior Antibacterial Activity of Photochemical Synthesized Ag-CNT Composites and their Synergistic Effects in Combination with other Antimicrobial Agents
}

Xiuli Dong1', Youngmi Koo², Yongan Tang ${ }^{3}$, Yeoheung Yun² and Liju Yang ${ }^{\text {** }}$

${ }^{1}$ Biomanufacturing Research Institute and Technology Enterprise (BRITE) and Department of Pharmaceutical Sciences, North Carolina Central University, Durham, NC 27707, USA

${ }^{2}$ Bioengineering, NSF ERC for Revolutionizing Metallic Biomaterials, North Carolina Agricultural and Technical State University, Greensboro, NC 27411, USA

${ }^{3}$ Department of Math and Physics, North Carolina Central University, Durham, NC 27707, USA

\begin{abstract}
Silver nanoparticle-modified multiwalled carbon nanotubes (MWCNTs) nanocomposites (AgCNTs) were synthesized by photochemical reduction method, their antimicrobial effect on both Gram negative and Gram positive bacteria, using E. coli and Bacillus anthracis as model bacteria, respectively, were investigated. The results indicated that AgCNTs exhibited more potent antibacterial effects against both Gram negative and Gram positive bacterium compared to Ag nanoparticles (Ag NPs). The minimal inhibitory concentrations (MICs) of AgCNTs against E. coli cells $(0.5 \mu \mathrm{g} / \mathrm{mL})$ and $B$. anthracis cells $(0.8 \mu \mathrm{g} / \mathrm{mL})$ was $1 / 20$ times and $1 / 17.5$ of the MICs of Ag NPs against $E$. coli and $B$. anthracis, respectively. Further study on the antibacterial effect of combination treatment of AgCNTs with oxidizing antimicrobial agents $\left(\mathrm{NaOCl}\right.$ or $\mathrm{H}_{2} \mathrm{O}_{2}$ ) to $E$. coli cells indicated a partial synergistic or a synergistic effect using the fractional inhibitory concentration ( $\mathrm{FIC}$ ) index test or isololograms. The combination treatment of AgCNTs with a natural peptide, nisin, also exhibited enhanced inhibitory effect on E. coli growth, as significant delays in growth of E. coli cells treated by the combination of $0.2 \mu \mathrm{g} / \mathrm{mL}$ AgCNTs and 4 or $8 \mu \mathrm{g} / \mathrm{mL}$ nisin was observed compared to AgCNTs alone nisin alone treatment. The synergistic or enhanced effect of the combination of AgCNTs with other antimicrobial relied on the combination of different action mechanisms in which AgCNTs played a role to damage cell membrane which allowed easier access for other small antimicrobial molecules to penetrate into cells. Such combination strategy could be broadly applicable to the improvement of existing antimicrobial methods or design/discover new effective antimicrobial agents/methods.
\end{abstract}

Keywords: Bacterial inhibition; Silver nanoparticle modified carbon nanotubes (AgCNTs); Synergistic effect; Combination treatment; $\mathrm{NaOCl} ; \mathrm{H}_{2} \mathrm{O}_{2}$; Nisin; E. coli; Bacillus anthracis

\section{Introduction}

Inactivation of pathogenic bacteria has been receiving great attention in the fields of environmental safety and public health. Traditional antimicrobial agents may be broadly classified into organic and inorganic materials. Organic antibacterial agents are often complex toxic bactericides that have strong inhibitory effects on bacterial growth, such as organic acids, essential oils, and bacteriocins. However, their low thermal stability, high toxicity, and short life expectancy have limited their applications in practice [1]. Inorganic agents, such as hypochlorite, alcohol, chlorine dioxide, hydrogen peroxide, triclosan, triclocarban, and some metal ions, are often less toxic and have received more and more recognition in the antibacterial product market in recent years [2,3]. Common inorganic antibacterial agents have been widely used in health-care and cleaning products. Besides these traditional antimicrobial agents, with the rapid growing field of nanotechnology in the past several years, a number of natural and engineered nanomaterials have been discovered for their strong antimicrobial properties for promising applications [4]. These nanomaterials include, but not limit to, metal nanoparticles, metal oxide nanoparticles, carbon-based nanoparticles and nanotubes. For example, silver nanoparticles (Ag NPs) are one of the metal nanoparticles that have been intensively studied as a bactericidal agent and their utilization is increasing owing to their strong antimicrobial properties and minimal toxicity [5]. Carbon nanotubes (CNTs), especially single-walled CNTs (SWCNTs), are one of the recently discovered antimicrobial agents against a variety of bacterial species [6-10], whereas multiwalled CNTs (MWCNTs) are found little or non-antimicrobial [11], but a good component in antimicrobial nanocomposite materials $[12,13]$.

In use of any of these traditional and newly emerged nanomaterialbased antimicrobial agents, leaching to the environment, soil, the groundwater and transported to surface waters, chemical residues as well as possible aggravated harmful disinfectant byproducts (DBPs) [4], often raise safety and health concerns. In some cases, direct contact with high concentration of antimicrobial agents may cause extensive damage to biological systems (like human tissues) [14]. One way to minimize such risk is to use low concentration of the antimicrobial agents, but in many cases, low concentration definitely compromises the antimicrobial effect. The use of combinations of different antimicrobial agents is a possible way to achieve high antimicrobial effect with low concentrations of individual agents, because the combination of appropriate agents can generate new effective antimicrobial molecules on-site or synergistically combine two different mechanisms to achieve

*Corresponding author: Liju Yang, Biomanufacturing Research Institute and Technology Enterprise (BRITE) and Department of Pharmaceutical Sciences, North Carolina Central University, Durham, NC 27707, USA, Tel: 1-919-530-6704; E-mail: lyang@nccu.edu

Received February 19, 2015; Accepted March 09, 2015; Published March 20, 2015

Citation: Dong X, Koo Y, Tang Y, Yun Y, Yang L (2015) Superior Antibacterial Activity of Photochemical Synthesized Ag-CNT Composites and their Synergistic Effects in Combination with other Antimicrobial Agents. J Nanomed Nanotechnol 6: 279. doi:10.4172/2157-7439.1000279

Copyright: ( 2015 Dong X, et al. This is an open-access article distributed under the terms of the Creative Commons Attribution License, which permits unrestricted use, distribution, and reproduction in any medium, provided the original author and source are credited. 
greater antimicrobial effect at relative low concentrations of individual agents. Such strategy has been demonstrated in some antimicrobial agents. For example, Fenton reagent has been reported as an effective sporicidal reagent to Bacillus spores [15], which combined hydrogen peroxide or ascorbic acid with various metal ions together in order to generate highly reactive hydroxyl radicals in the immediate vicinity of their targets [16-18]. The combination of $\mathrm{NaOCl}$ and vitamin $\mathrm{B} 1$ treatment on total aerobic bacteria and E. coli contaminating head lettuce Lactuca sativa showed a significant synergistic effect [19]. Combination of hydrogen peroxide and formic acid showed synergistic antimicrobial effect on six bacterium strains which were representative of contamination bacteria in the food industry [20]. Besides these chemical agents, such combination also works for nanomaterialbased antimicrobial agents. For example, Ag NPs attached to CNTs showed enhanced antimicrobial activity against E. coli [13], because the presence of CNTs in nanoparticles composites can act as a host to increase the long term stability of Ag nanoparticles. They also found that the antibacterial activity of Ag NP-CNTs was dependent on the size of Ag NPs. Jung et al. [12] synthesized Ag-coated CNTs by the use of a simple aerosol technique and prepared AgCNTs-deposited filters. These filters exhibited higher antimicrobial activity than CNTs- and Ag NPs-deposited filters. Additionally, AgCNTs have received attention due to their potential applications as catalysts [21,22], reinforcing agents [23], and advanced materials [24,25].

In this study, photochemically synthesized AgCNTs was evaluated for their antibacterial effects on both Gram-positive bacteria and Gram-negative bacteria using B. anthracis and E. coli as model bacteria, respectively. Further, the combination of AgCNTs with oxidizing antibacterial agents or natural antibacterial agents was studied to determine whether synergistic antimicrobial effect would present on both Gram positive and Gram negative bacteria. Tested oxidizing agents in the combination with AgCNTs included sodium hypochlorite $(\mathrm{NaOCl})$ and hydrogen peroxide $\left(\mathrm{H}_{2} \mathrm{O}_{2}\right)$, and the tested natural antimicrobial peptide was- nisin. $\mathrm{NaOCl}$ is the effective component of many commercial disinfectants. When $\mathrm{NaOCl}$ is used at high concentration, it causes mucous membranes irritation, infraclinical damage on intact skin [26], deterioration in organoleptic quality, an unpleasant odor, residual chlorine, and production of byproducts including the carcinogenic substance trihalomethane [27,28]. Hydrogen peroxide is a powerful oxidizer and an efficient disinfectant. It degrades completely into water and oxygen without producing salt residues. Its safety depends on the applied concentration. For disinfection purpose, high concentrations are required, which raise safety issues. For example, exposure of eyes to $5 \%$ of higher $\mathrm{H}_{2} \mathrm{O}_{2}$ leads to permanent eye damage. In addition, $\mathrm{H}_{2} \mathrm{O}_{2}$ irritates lung by inhalation and causes blisters, burns, and whitening on skin after direct contact. Laboratory tests on bacteria show that $\mathrm{H}_{2} \mathrm{O}_{2}$ is mutagenic, causing DNA damage. Because of the potential risk raised by the use of high concentrations of such oxidizing agents, the use of lower concentrations of these agents are advised, but the fact is lower concentrations are less effective [29]. Nisin is a polycyclic antibacterial peptide with 34 amino acid residues and is produced by bacterium pellet was rinsed with deionized water repeatedly. Synthesized AgCNTs were then dried at $80^{\circ} \mathrm{C}$ under vacuum overnight.

\section{Methods}

Characterization of AgCNTs by scanning electron microscopy (SEM) and energy-dispersive X-ray spectroscopy (EDX)

The surface morphology and size of AgCNT nanocomposites were examined by field emission-scanning electron microscope (FE-SEM) (Hitachi 8000). FE-SEM imaging was operated at $10 \mathrm{kV}$. EDX data were obtained with a Bruker AXS (XFlash detector 5030) coupled with the FE-SEM. Three typical regions of each sample were analyzed, and the average wt.\% of each element in AgCNTs composites was determined.

\section{Evaluation of concentration-dependent antibacterial activity of AgCNTs on E. coli K12 cells and Bacillus anthracis cells by optical density (OD) measurement}

The experiments were performed in 96-well plates. Bacterial cells were prepared as follows. Bacterial cells were grown in Nutrient broth overnight and were diluted in fresh Nutrient broth to desired concentrations for each experiment. Aliquots of $100 \mu \mathrm{L}$ diluted cells in nutrient broth at approximately $6.5 \times 10^{5}$ cells $/ \mathrm{mL}$ were dispersed into the wells of a 96-well plate. Desired volumes of AgCNTs solution were added into the wells to reach the concentrations of $0.2,0.4,0.5$, $0.6,0.7,0.8$, and $1 \mu \mathrm{g} / \mathrm{mL}$, in a total volume of $150 \mu \mathrm{L}$ in each well by adjusting with deionized (DI) $\mathrm{H}_{2} \mathrm{O}$. The plates were incubated at $37^{\circ} \mathrm{C}$ for $24 \mathrm{~h}$. OD measurements were performed using the Spectra Max M5 spectrophotometer (Molecular Devices, LLC, Sunnyvale, CA). The changes in optical density (OD) at $595 \mathrm{~nm}$ of the samples after incubation were compared as an indicator of the growths of treated cells, and thus for evaluating the inhibition effect of AgCNTs to bacterial cells. For comparison, the antibacterial effects of $\mathrm{Ag}$ nanoparticles (NPs) without CNTs were also tested using the same method.

\section{Treatment with AgCNTs and Ag NPs and determination of viable cell reduction}

A freshly grown overnight $E$. coli $\mathrm{K} 12$ culture was washed 3 times and resuspended in PBS. The washed cells were then treated with Ag NPs or AgCNTs. The treatment was performed in $1.5 \mathrm{ml}$ centrifuge tubes. Each tube included $900 \mu \mathrm{L}$ bacterial cells, $0.3 \mu \mathrm{g} / \mathrm{mL}$ AgCNTs or $5 \mu \mathrm{g} / \mathrm{mL}$ Ag NPs, and adjusted to the final volume of $1 \mathrm{~mL}$ by addition of DI- $\mathrm{H}_{2} \mathrm{O}$. Controls contained $900 \mu \mathrm{L}$ bacterial cells and 100 $\mu \mathrm{L}$ DI water. The tubes were rotated at $15 \mathrm{rpm}$ at room temperature for $0,15,30$, or 60 min on a Dynal rotator (Dynal biotech Inc., Lake Success, NY). After the treatment, viable cell numbers of all the samples were determined by the traditional plating method. For each sample, serial 1:10 dilutions were made, and aliquots of $100 \mu \mathrm{L}$ of appropriate dilutions were surface plated on Luria-Bertani (LB) agar plates. Colony numbers were counted after $18 \mathrm{~h}$ incubation at $37^{\circ} \mathrm{C}$, and colony forming units (CFU) per $\mathrm{mL}$ were calculated.

\section{Fractional inhibitory concentration (FIC) index test for the combination of AgCNTs and $\mathrm{NaOCl}$ or $\mathrm{H}_{2} \mathrm{O}_{2}$}

To investigate whether there were synergistic effect in the combination of AgCNTs with $\mathrm{NaOCl}$ or $\mathrm{H}_{2} \mathrm{O}_{2}$, FIC index test was performed and isobolograms were generated. To do this, a broth microdilution checkerboard method was used based on the recommendations of NCCLS [30-33]. Aliquots of $100 \mu \mathrm{L}$ of E. coli cells in Nutrient broth were distributed into each well of 96-well plates. AgCNTs solution and $\mathrm{NaOCl}$ or $\mathrm{H}_{2} \mathrm{O}_{2}$ were added to the wells at various volumes to achieve 2 -fold serial dilutions along the ordinate and the abscissa of the plates, respectively. The final volume in each well was adjusted to $150 \mu \mathrm{L}$ by adding desired volume of DI $\mathrm{H}_{2} \mathrm{O}$. The resulting checkerboard contained each combination of AgCNTs and $\mathrm{NaOCl}$ or $\mathrm{H}_{2} \mathrm{O}_{2}$ at different concentrations. The plates were incubated at $37^{\circ} \mathrm{C}$ for $48 \mathrm{~h}$. OD values at $595 \mathrm{~nm}$ of all samples were read before and after the incubation. Increase in OD indicated bacterial growth, while no change on OD indicated no bacterial growth. Based on the OD measurement 
of bacterial growth, the minimal inhibitory concentrations (MICs) of each agent or combined agents was determined, which was the lowest concentration of the agent(s) causing complete inhibition of bacterial growth. Then, the FIC index $(\Sigma F I C)$ was calculated as follows: $\Sigma$ FIC=FIC of agent A + FIC of agent B, where FIC of agent $\mathrm{A}=\mathrm{MIC}$ of agent $\mathrm{A}$ in combination/MIC of agent $\mathrm{A}$ alone, and FIC of agent $\mathrm{B}=\mathrm{MIC}$ of agent $\mathrm{B}$ in combination/MIC of agent $\mathrm{B}$ alone. The combination effect was determined according to the resulting FIC index as follows: FIC index $<0.5$ indicates synergy; FIC index 0.5-0.75 indicates partial synergy; FIC index 0.75-1.0 indicates additive effect; FIC index 1.0-4.0 indicates indifference, and FIC index $>4$ indicates antagonism, respectively [34].

\section{Isobologram}

The FIC values were plotted on an isobologram of AgCNTs versus $\mathrm{NaOCl}$ or $\mathrm{H}_{2} \mathrm{O}_{2}$ to graphically visualize any interactions between the two reagents. In an isobologram, the concentrations of the two reagents are plotted on the $\mathrm{x}$ - and $\mathrm{y}$-axis. Then the MIC of each reagent is plotted on the graph and the two data points are joined by a line. The MICs of mixed reagents are plotted and joined by another line and compared with the previous line. If the line of the mixed MICs lies below the line of individual MICs, the interaction between the two agents is synergistic; If it is above the previous line, the interaction is antagonistic; and if it is on the previous line, there is no interaction between the agents [35].

\section{Results and Discussion}

\section{Characterization of AgCNTs}

The EDX elemental microanalysis results showed that the average content of element $\mathrm{C}, \mathrm{O}$, and $\mathrm{Ag}$ were $74.63 \%, 15.00 \%$, and $10.37 \%$, respectively, which further confirmed the presence of Ag NPs on CNTs. In this hybrid nanocomposite, the role of acid-treated MWCNTs was to stabilize Ag NPs [36]. The stabilizing mechanism was proposed as follows: the oxygen elements on the walls of the acid-treated MWCNTs provided the nucleation centers for $\mathrm{Ag}$ ion and then stabilized the $\mathrm{Ag}$ nanoparticles after they were formed. The formed Ag nanoparticles were able to line up on the MWCNTs' surfaces, producing a stable assembly due to the special structures [36,37]. To completely inhibit the growth of Gram negative bacteria $E$. coli $\mathrm{K} 12$ cells, the minimal concentrations of Ag NPs and AgCNTs were $10 \mu \mathrm{g} / \mathrm{mL}$ and $0.5 \mu \mathrm{g} / \mathrm{mL}$, respectively (Figures $1 \mathrm{~A}$ and $1 \mathrm{~B}$ ). To completely inhibit the growth of Gram positive bacteria $B$. anthracis, the minimal concentrations of Ag NPs and AgCNTs were $14 \mu \mathrm{g} / \mathrm{mL}$ and $0.8 \mu \mathrm{g} / \mathrm{mL}$, respectively (Figures $1 \mathrm{C}$ and 1D). The minimal inhibitory concentration (MIC) of AgCNTs to E. coli and B. anthracis cells were $1 / 20$ to $1 / 17.5$ of those of Ag NPs, respectively, indicating that AgCNTs exhibited more potent inhibitory effect against both types of cells than Ag NPs did.

It is noted that AgCNTs exhibited slightly stronger inhibitory effect on Gram negative E. coli cells than Gram positive B.anthracis cells. This was true to Ag NPs too. This observation might be resulted from the distinct structure of cells between Gram-negative and Gram-positive bacteria. In Gram negative bacteria, the cell wall is a 7-8 $\mathrm{nm}$ thick layer of peptidoglycan which is sandwiched between an inner cell membrane and an outer membrane, whereas Gram-positive bacteria has a cell wall of 20-80 nm thick layer of peptidoglycan without an outer membrane. The peptidoglycan is a meshlike exoskeleton similar in function to the exoskeleton of an insect, consisting of sugars and amino acids. The Gram-positive cell wall may also include other components such as teichoic and lipoteichoic acids and complex polysaccharides, which can act as chelating agents. The peptidoglycan layer is essential for the
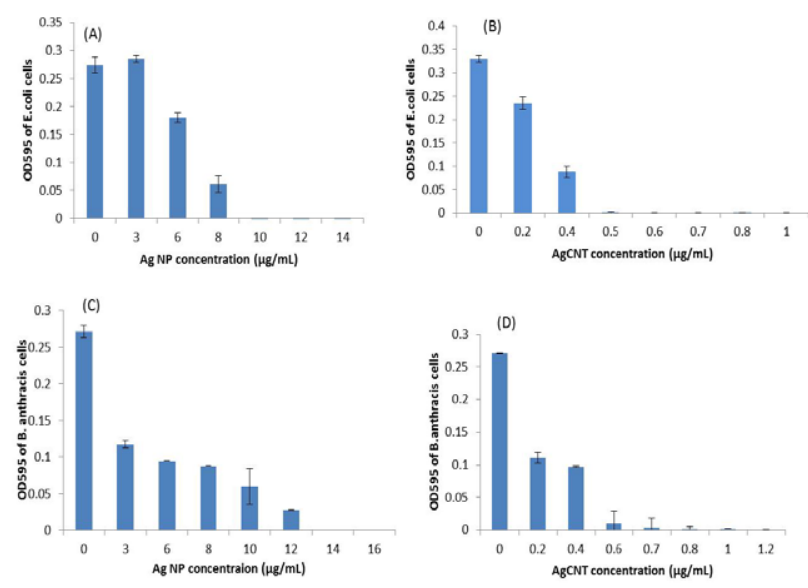

Figure 1: Concentration effects of Ag NPs and AgCNTs on E. coli cells (A and $B$ ) and $B$. anthracis cells (C and D) after $24 \mathrm{~h}$ incubation at $37^{\circ} \mathrm{C}$.

structure and for survival in the normally hostile conditions in which bacteria grow. It protects bacteria against antibacterial agents such as antibiotics, toxins, chemicals, and degradative enzymes [38].

It is also noted that the photochemical synthesized AgCNTs in this study showed much stronger antibacterial effect than the AgCNTs reported in a previous study [38], where the reported MIC of AgCNTs to E. coli cells was $130 \mu \mathrm{g} / \mathrm{mL}$. Yu et al. [39] synthesized Ag NPs/ Halloysite nanotubes/graphene nanocomposites with sandwich-like structure, and the MIC to E. coli was $2 \mu \mathrm{g} / \mathrm{mL}$. It is believed that the synthesis approach thus the resulting actual structure of AgCNTs, the density, and the size of Ag NPs on CNTs are factors that affect the inhibitory effect of the hybrid AgCNTs to bacterial cells. However, the correlation between these factors and the inhibitory effect will need a more systematic study and is not within the scope of this study.

To further investigate the inhibitory effect of AgCNTs during bacterial growth, the dynamic growth curve of $E$. coli cells in the presence of $0.3 \mu \mathrm{g} / \mathrm{mL}$ AgCNTs was monitored using OD measurement, along with the growth curves in the presence of equal concentration of $\mathrm{Ag}$ NPs $(0.3 \mu \mathrm{g} / \mathrm{mL})$, equivalent concentration of Ag NPs $(5 \mu \mathrm{g} / \mathrm{mL})$, and the control (Figure 2A). Figure 2A indicated that $0.3 \mu \mathrm{g} / \mathrm{mL}$ AgCNTs effectively inhibited the $E$. coli cell growth, whereas AgNPs at the same concentration did not show inhibitory effect. Elevated concentration of Ag NPs to $5 \mu \mathrm{g} / \mathrm{mL}$ showed an inhibitory effect approximately equivalent to $0.3 \mu \mathrm{g} / \mathrm{mL}$ AgCNTs on E.coli cell growth. To reach the OD595 value of $0.2, E$. coli cells demonstrated $6.2,5.85$, and $0 \mathrm{~h}$ delay after being treated with $0.3 \mu \mathrm{g} / \mathrm{mL}$ AgCNTs, $5 \mu \mathrm{g} / \mathrm{mL}$ Ag NPs, and $0.3 \mu \mathrm{g} / \mathrm{mL}$ Ag NPs, respectively. The growth curve results further confirmed the stronger inhibitory effect of AgCNTs than Ag NPs on bacterial growth.

\section{Viable cell reduction in pre-treatment with AgCNTs}

We further investigated the effect of pre-treatment with AgCNTs on the inactivation of bacterial cells, as well as the treatment time dependency. As seen in Figure 2A, AgCNTs and Ag NPs at the concentration of $0.3 \mu \mathrm{g} / \mathrm{mL}$ and $5 \mu \mathrm{g} / \mathrm{mL}$, respectively, had approximately equivalent inhibition effect on bacterial growth, so we selected to use these concentrations of AgCNTs and Ag NPs to treat E. coli cells for 15 to $60 \mathrm{~min}$, and the reductions in viable cell number after these treatments were determined by the plating method. Figure $2 \mathrm{~B}$ shows that the viable cell reduction in logarithmic value after the 

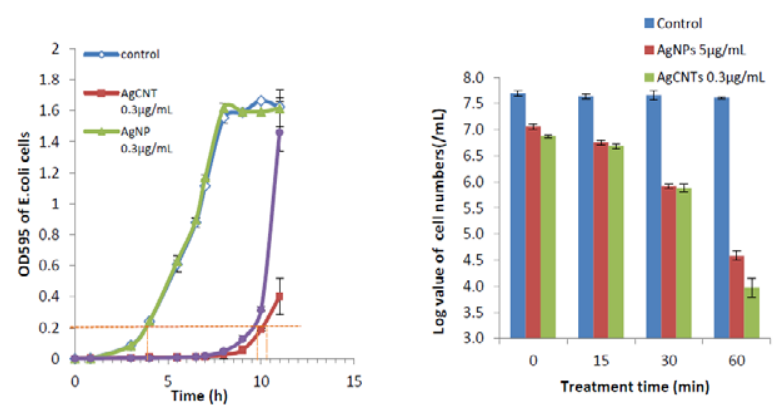

Figure 2: (A) The growth curves of $E$. Coli cells in the presence of Ag NPs $(0.3$ and $5 \mu \mathrm{g} / \mathrm{mL})$ and $\mathrm{AgCNTs}(0.3 \mu \mathrm{g} / \mathrm{mL})$; (B) Logarithmic values of $E$. coli cell number in cfu/mL in controls and the samples treated with $0.3 \mu \mathrm{g} / \mathrm{mL}$ AgCNTs and $5 \mu \mathrm{g} / \mathrm{mL}$ Ag NPs for various treatment time.

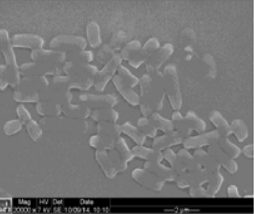

(A) Untreated E. coli cell

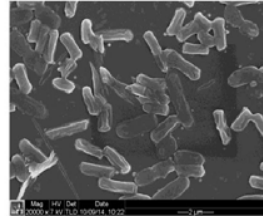

(B) Ag NPs treated cells

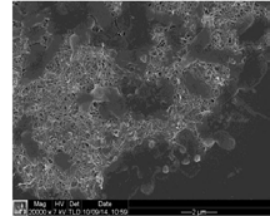

(C) AgCNTs treated cells
Figure 3: SEM images of $E$. coli cells at 50,000x magnification. (A) Untreated control bacteria; (B) Bacteria treated with Ag NPs; (C) Bacteria treated with AgCNTs.

treatments with AgCNTs and Ag NPs for various periods of time. As shown in Figure 2B, upon the immediate mixing with $0.3 \mu \mathrm{g} /$ $\mathrm{mL}$ AgCNTs, the viable cell number reduced $0.82 \log$ (equivalent to $85.75 \%)$. As the treatment time prolonged, the viable cell reduced more. Upon $60 \mathrm{~min}$ treatment with $0.3 \mu \mathrm{g} / \mathrm{mL}$ AgCNTs, the viable E. coli cell number reduced by $3.64 \log$ (equivalent to $99.98 \%$ ). Not surprisingly, treatments with $5 \mu \mathrm{g} / \mathrm{ml} \mathrm{Ag} \mathrm{NPs} \mathrm{showed} \mathrm{a} \mathrm{similar} \mathrm{trend}$ and similar magnitudes in viable cell reduction, as $15 \mathrm{~min}$ and $60 \mathrm{~min}$ treatments produced $0.64 \mathrm{log}$ reduction (equivalent to $77.2 \%$ ) and 3.02 $\log$ reduction (equivalent to $99.91 \%$ ), respectively. The results here indicated that the inactivation effect of AgCNTs to bacterial cells were effective upon immediate contact and increased with the increasing treatment time. This observation is consistent with observations on the antibacterial activities of Ag NPs or Ag NPs composites reported in other studies, including studies demonstrated that Ag NPs inhibited the bacterial growth rate from the time of first contact [40], and other studies showed that the Ag-impregnated polymers had an improved antibacterial characteristic with increased contact time [41].

We further used SEM microscopy to examine the morphology changes of $E$. coli cells before and after being treated with Ag NPs or AgCNTs. Figure $3 \mathrm{~A}$ shows that the untreated $E$. coli cells, which were intact and rod - shaped with well-defined membranes. After being treated with Ag NPs $15 \mu \mathrm{g} / \mathrm{mL}$ for $30 \mathrm{~min}$, some cells were ruptured or fragmented, and some appeared irregular in shape while others were intact and not much change in morphology compared to the untreated cells (Figure 3B). After $30 \mathrm{~min}$ treatment with $1 \mu \mathrm{g} / \mathrm{mL}$ AgCNTs, almost all the cells were ruptured and turned flat on AgCNTs (Figure 3C), such obvious cell damages by AgCNTs proved the effectiveness of their much stronger antibacterial activity compared to Ag NPs.

Looking into the mechanisms of AgCNTs for inhibiting/ inactivating bacterial cells, it is accepted that the stronger antibacterial activity of AgCNTs comes from the synergistic effect of Ag NPs and MWCNTs. Several mechanisms on how AgCNTs inactivate bacterial cells have been proposed. Some studies indicated that in an aquatic environment, Ag NPs attached on CNTs partially dissolve in aquatic solution and generate low concentration silver ions $\left(\mathrm{Ag}^{+}\right)$, and the released $\mathrm{Ag}^{+}$ions bind to the thiol group ( $\mathrm{SH}$ ) of enzymes and proteins on bacterial surfaces and interrupt the adenosine triphosphate (ATP) pathway, leading to destabilization of bacterial membranes and walls [13]. Other studies proposed that AgCNTs interact with bacterial membrane and generate free radicals reactive oxygen species (ROS) on site, which induce membrane damage [38]. Other proposed mechanism suggested that AgCNTs physically pierce bacterial membrane and wall, which allow the penetration of $\mathrm{Ag}^{+}$as well as Ag NPs into the internal of bacteria cells and inactivate them [42]. In Fact, Ag NPs accumulations on bacterial cell membrane, the lipopolysaccharide layer in the cell wall, and deep inside bacterial cells were observed by SEM, TEM, and STEM (scanning tunneling electron microscope) tests [43]. Significant morphological changes, including pits and cracks on cell membrane, as well as fragmentary membrane, were also observed on Ag NPs-treated cells [44]. Some other studies suggested that the main role of MWCNTs in the AgCNTs hybrids was to effectively stabilizing Ag NPs because the formation of Ag NPs and CNTs hybrids significantly reduced the reunion of Ag NPs and prevented them from aggregation, which was a factor that greatly affect the effectiveness of Ag NPs' antibacterial activities [45]. While each of these proposed mechanisms is reasonable from a certain point of view and each has supportive evidence, they
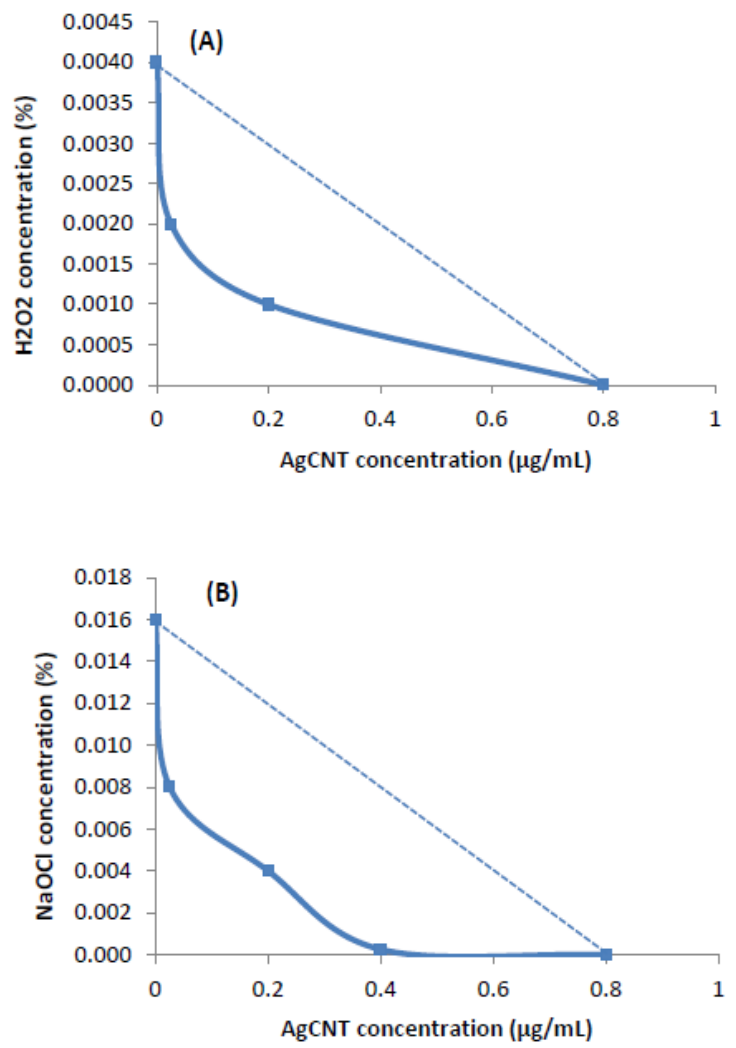

Figure 4: Isobologram of the interaction between $\mathrm{AgCNTs}$ and $\mathrm{H}_{2} \mathrm{O}_{2}(A)$, and between $\mathrm{AgCNTsand} \mathrm{NaOCl}(\mathrm{B})$ against $E$. coli cells. Dash line is the line of MICs of individual agents, and the solid line is the line of MICs of combination treatments. 
do not exclude each other; and most likely, these mechanisms work together. But much work is still necessary to fully understand and elucidate the detailed mechanisms of AgCNTs for inactivation of bacterial cells.

\section{Antibacterial effect of the combination of AgCNTs and oxidizing agents}

Another way to examine whether a synergistic effect exist is to use the isobologram. Figure $4 \mathrm{~A}$ shows the isobologram of the combination treatment with $\mathrm{AgCNTs}$ and $\mathrm{H}_{2} \mathrm{O}_{2}$, where the line of MICs in the combination treatment lies below the line linking the MICs of individual AgCNTs and $\mathrm{H}_{2} \mathrm{O}_{2}$, indicating a synergistic effect between AgCNTs and $\mathrm{H}_{2} \mathrm{O}_{2}$. Similar isobologram was obtained for the combination treatment with AgCNTs and $\mathrm{NaOCl}$ (Figure 4B), which indicated a synergistic effect between AgCNTs and $\mathrm{H}_{2} \mathrm{O}_{2}$ in inhibition of $E$. coli cells. The synergistic effect roots back from a multiple-damage mechanism in which two different disinfection methods enhance their antibacterial activity by damaging the microorganisms in different ways [46]. When AgCNTs were combined with $\mathrm{NaOCl}$ or $\mathrm{H}_{2} \mathrm{O}_{2}$, the damages in cell walls and membranes caused by AgCNTs led to more penetration of the active antimicrobial components into the cells and more effectively inactivate to cells.

$\mathrm{NaOCl}$ and $\mathrm{H}_{2} \mathrm{O}_{2}$ are oxidative antimicrobials and typically work by forming ROS to inactivate bacterial cells. Looking into its reaction in aquatic solution, $\mathrm{NaOCl}$ exhibits a dynamic equilibrium as the following equation:

$$
\mathrm{NaOCl}+\mathrm{H}_{2} \mathrm{O} \leftrightarrow \mathrm{NaOH}+\mathrm{HOCl} \leftrightarrow \mathrm{Na}^{+}+\mathrm{OH}^{-}+\mathrm{H}^{+}+\mathrm{OCl}^{-}
$$

The produced hypochlorous acid $(\mathrm{HOCl})$ is the key microbicidal component owing to its great potency as a nucleophilic non-radical oxidant and its efficacy lies in the fact that neither bacteria nor mammalian cells can counteract its toxic effect since they lack the enzymes required for its catalytic detoxification [47]. HOCl is known to react with primary amines and other $\mathrm{n}$-compounds to rapidly yield chloramines and nitrogen-chlorine derivatives $[14,48]$. At the molecular level, a study on the genome-wide transcriptome response to $\mathrm{NaOCl}-$ induced oxidative stress in $P$. aeruginosa revealed a downregulation of virtually all genes related to oxidative phosphorylation and electron transport and an upregulation of many organic sulfur transport and metabolism genes [49]. The inactivation efficiency of $\mathrm{NaOCl}$ is also dependent on other factors including $\mathrm{pH}$ value and bacteria species. The high $\mathrm{pH}$ of $\mathrm{NaOCl}$ interferes in the cytoplasmic membrane integrity [50]. Different bacterial species have different resistance to $\mathrm{NaOCl}$ [14]. It was reported that the theoretical $\mathrm{NaOCl}$ concentration required for total bacteriacidal effects is high $(\geq 0.5 \%)$, which causes health issue for human beings. The LD50 was $290 \mathrm{mg} / \mathrm{kg}$ of an oral dose and $33.3 \mathrm{mg} /$ $\mathrm{kg}$ of an intravenous dose, which was obtained by single-dose toxicity studies in rats using $1.1 \% \mathrm{NaOCl}$ solutions [51].

$\mathrm{H}_{2} \mathrm{O}_{2}$ is thermodynamically unstable and produces hydroxyl free radicals, which are highly reactive and attack DNA, RNA, proteins, and lipids in microbes [52]. A 3-6\% (v/v) solution is widely used as an antiseptic and general surface disinfectant. $\mathrm{H}_{2} \mathrm{O}_{2}$ at the concentration of $16.3 \mathrm{mM}$ was highly inhibitory for glycolysis and mainly bacteriostatic for Streptococcus mutans [53]. The killing effect of $\mathrm{H}_{2} \mathrm{O}_{2}$ is timedependent. The concentration of $\mathrm{H}_{2} \mathrm{O}_{2}$ required to kill half the oral streptococci within $15 \mathrm{~s}$ was $1.8 \mathrm{M}(6 \%)$, but fell to $0.3 \mathrm{M}(1 \%)$ at 2 min, and to $10 \mathrm{mM}(0.03 \%)$ at $1 \mathrm{~h} \mathrm{[54]} . \mathrm{H}_{2} \mathrm{O}_{2}$ is sometimes mixed with colloidal silver. The combination treatment with AgCNTs and $\mathrm{NaOCl}$ or $\mathrm{H}_{2} \mathrm{O}_{2}$ enhanced the inactivation efficiency for E. coli compared to the treatment with $\mathrm{NaOCl}$ or $\mathrm{H}_{2} \mathrm{O}_{2}$ alone at the same concentration and treatment conditions Such combination treatments were able to achieve enhanced bacterial inactivation/inhibition than individual agent at the same concentration, hence reduced the risk of using high concentration of each individual agents.

\section{Inhibitory effect of combination treatment with AgCNTs and nisin on $E$. coli cells}

Nisin is a polycyclic antibacterial peptide with 34 amino acid residues and is produced by bacterium Lactococcus lactis. It has highly antibacterial activity against Gram positive bacteria, but Gram negative bacteria generally are not sensitive to nisin [30]. Nisin's antimicrobial mechanism is that it binds to the cell membrane through ionic interactions of the C-terminus and forms pores in the membrane by the penetration of the hydrophobic $\mathrm{N}$-terminus [55]. The actual action involves interactions with the membrane-bound cell wall precursor lipid II (undecaprenylpyrophosphoryl-MurNAc-(pentapeptide)GlcNac), concomitant with pore formation in the cytoplasmic membrane of the target organism [56]. Sometimes, its low solubility and stability at neutral $\mathrm{pH}$ limit its effectiveness and result in an inconsistent preservative action against Gram positive food pathogens and against food spoilage [57].

In this study, we examined the possibility of using the combination of AgCNTs with nisin on Gram negative bacteria using E. coli $\mathrm{K} 12$ a model organism. The growth curves of $E$. coli cells in the presence of nisin, AgCNTs, and the combination of AgCNTs and nisin, along with the controls. The presence of 4 or $8 \mu \mathrm{g} / \mathrm{mL}$ nisin, the cell growth curves were similar to the control during $25 \mathrm{~h}$ of growth, which indicated that nisin did inhibit the growth of Gram negative bacteria. No effective inhibition was observed even in the presence of $500 \mu \mathrm{g} / \mathrm{mL}$ nisin during $24 \mathrm{~h}$ incubation at $37^{\circ} \mathrm{C}$ (data not shown). Other studies observed similar results on Gram negative E. coli O157:H7 (ATCC43895) after being treated with $320 \mathrm{AU} / \mathrm{mL}$ partially-purified nisin $\mathrm{Z}$ [58]. The ineffectiveness of nisin against Gram negative believed that this combination strategy is broadly applicable to improve the efficiency of existing antimicrobial agents/methods or design/discover new effective antimicrobial agents/methods.

\section{Acknowledgement}

This research was partially supported by the U.S. Department of Agriculture (USDA) grant 2014-67017-21706.

\section{References}

1. Kim JD, Yun H, Kim GC, Lee CW, Choi HC (2013) Antibacterial activity and reusability of CNT-Ag and GO-Ag nanocomposites. Applied Surface Science 283: $227-233$.

2. Fang M, Chen JH, Xu XL, Yang PH, Hildebrand HF (2006) Antibacterial activities of inorganic agents on six bacteria associated with oral infections by two susceptibility tests. Int J Antimicrob Agents 27: 513-517.

3. Wang XJ, Qiao XL, Chen JG, Wang HS, Ding SY (2003) Advancement in research on inorganic antibacterial material. J Ceram 24: 239-244.

4. Li Q, Mahendra S, Lyon DY, Brunet L, Liga MV, et al. (2008) Antimicrobial nanomaterials for water disinfection and microbial control: potential applications and implications. Water Res 42: 4591-4602.

5. Lok CN, Ho CM, Chen R, He QY, Yu WY, et al. (2007) Silver nanoparticles: partial oxidation and antibacterial activities. J Biol Inorg Chem 12: 527-534.

6. Aferchich K, Lilly M, Yang L (2012) Effect of single-walled carbon nanotubes on Bacillus anthracis cell growth, sporulation, and spore germination. J Nanosci Nanotechnol 12: 3821-3830.

7. Arias LR, Yang L (2009) Inactivation of bacterial pathogens by carbon nanotubes in suspensions. Langmuir 25: 3003-3012. 
Citation: Dong X, Koo Y, Tang Y, Yun Y, Yang L (2015) Superior Antibacterial Activity of Photochemical Synthesized Ag-CNT Composites and their Synergistic Effects in Combination with other Antimicrobial Agents. J Nanomed Nanotechnol 6: 279. doi:10.4172/2157-7439.1000279

Page 6 of 7

8. Liu S, Ng AK, Xu R, Wei J, Tan CM, et al. (2010) Antibacterial action of dispersed single-walled carbon nanotubes on Escherichia coli and Bacillus subtilis investigated by atomic force microscopy. Nanoscale 2: 2744-2750.

9. Yang C, Mamouni J, Tang Y, Yang L (2010) Antimicrobial activity of singlewalled carbon nanotubes: length effect. Langmuir 26: 16013-16019.

10. Kang S, Herzberg M, Rodrigues DF, Elimelech M (2008) Antibacterial effects of carbon nanotubes: size does matter! Langmuir 24: 6409-6413.

11. Jung JH, Hwang GB, Lee JE, Bae GN (2011) Preparation of airborne Ag/ CNT hybrid nanoparticles using an aerosol process and their application to antimicrobial air filtration. Langmuir 27: 10256-10264.

12. Kazmi SJ, Shehzad MA, Mehmood S, Yasar M, Naeem A (2014) Effect of varied $\mathrm{Ag}$ nanoparticles funtionlized CNTs on its antibacterial activity agains E.coli. Sensors and Actuators A: Physical 216: 287-294.

13. Hidalgo E, Bartolome R, Dominguez C (2002) Cytotoxicity mechanisms of sodium hypochlorite in cultured human dermal fibroblasts and its bactericidal effectiveness. Chem Biol Interact 139: 265-282.

14. Shapiro MP, Setlow B, Setlow $P$ (2004) Killing of Bacillus subtilis spores by a modified Fenton reagent containing $\mathrm{CuCl} 2$ and ascorbic acid. Appl Environ Microbiol 70: 2535-2539.

15. Cross JB, Currier RP, Torraco DJ, Vanderberg LA, Wagner GL, et al. (2003) Killing of bacillus spores by aqueous dissolved oxygen, ascorbic acid, and copper ions. Appl Environ Microbiol 69: 2245-2252.

16. Sagripanti JL (1992) Metal-based formulations with high microbicidal activity Appl Environ Microbiol 58: 3157-3162.

17. Wardman P, Candeias LP (1996) Fenton chemistry: an introduction. Radia Res 145: 523-531.

18. Ha JH, Lee JY, Chung MS, Park J, Ha SD (2013) Synergism of Combined Vitamin B1 and Naocl Treatment for the Reduction of Microbiological Contamination in Head Lettuce. Journal of Food Processing and Preservation 37: 86-92

19. Martin $\mathrm{H}$, Maris $\mathrm{P}$ (2012) Synergism between hydrogen peroxide and seventeen acids against six bacterial strains. J Appl Microbiol 113: 578-590.

20. Guo DJ, Li HL (2005) Highly dispersed Ag nanoparticles on functional MWNT surfaces for methanol oxidation in alkaline solution. Carbon 43: 1259-1264.

21. Yang GW, Gao GY, Wang C, Xu CL, Li HL (2008) Controllable deposition of $\mathrm{Ag}$ nanoparticles on carbon nanotubes as a catalyst for hydrazine oxidation. Carbon 46: 747-752.

22. Rangari VK, Mohammad GM, Jeelani S, Hundley A, Vig K, et al. (2010) Synthesis of $\mathrm{Ag} / \mathrm{CNT}$ hybrid nanoparticles and fabrication of their nylon-6 polymer nanocomposite fibers for antimicrobial applications. Nanotechnology 21: 095102.

23. Ma PC, Tang BZ, Kim JK (2008) Effect of CNT decoration with silver nanoparticls on electrical conductivity of CNT-polymer composites. Carbon 46: 1497-1505.

24. Wildgoose GG, Banks CE, Compton RG (2006) Metal nanoparticles and related materials supported on carbon nanotubes: methods and applications. Small 2: 182-193.

25. Goffin V, Piérard GE, Henry F, Letawe C, Maibach HI (1997) Sodium hypochlorite, bleaching agents, and the stratum corneum. Ecotoxicol Environ Saf 37: 199-202.

26. Kim C, Choi SH, Lee YJ, Choi HC, Jeon DH, et al. (2008) Study on the safety evaluation management system of disinfectants and sanitizer. J Food Hyg Safety 3: 18-25.

27. Lee NY, Kim SW, Ha SD (2014) Synergistic effects of ultrasound and sodium hypochlorite $(\mathrm{NaOCl})$ on reducing Listeria monocytogenes ATCC19118 in broth, stainless steel, and iceberg lettuce. Foodborne Pathog Dis 11: 581-587.

28. Câmara AC, de Albuquerque MM, Aguiar CM, de Barros Correia AC (2009) In vitro antimicrobial activity of $0.5 \%, 1 \%$, and $2.5 \%$ sodium hypochlorite in roo canals instrumented with the ProTaper Universal system. Oral Surg Oral Med Oral Pathol Oral Radiol Endod 108: e55-61.

29. Stevens KA, Sheldon BW, Klapes NA, Klaenhammer TR (1991) Nisin treatmen for inactivation of Salmonella species and other gram-negative bacteria. App Environ Microbiol 57: 3613-3615.
30. Cleveland J, Montville TJ, Nes IF, Chikindas ML (2001) Bacteriocins: safe, natural antimicrobials for food preservation. Int J Food Microbiol 71: 1-20.

31. Murdock CA, Cleveland J, Matthews KR, Chikindas ML (2007) The synergistic effect of nisin and lactoferrin on the inhibition of Listeria monocytogenes and Escherichia coli O157:H7. Lett Appl Microbiol 44: 255-261.

32. NCCLS (2003) Methods for dilution susceptibility tests for bacteria that grow aerobically.

33. Kumar KA, Mazumdar K, Dutta NK, Karak P, Dastidar SG, et al., (2004) Evaluation of synergism between the aminoglycoside antibiotic streptomycin and the cardiovascular agent amlodipine. Biological \& Pharmaceutical Bulletin 27: 1116-1120.

34. Roks G, Deckers CL, Meinardi H, Dirksen R, van Egmond J, et al. (1999) Effects of polytherapy compared with monotherapy in antiepileptic drugs: an animal study. J Pharmacol Exp Ther 288: 472-477.

35. Zhao W, Li M, Zhang Z, Peng H (2010) EMI shielding effectiveness of silver nanoparticle-decorated multi-walled carbon nanotube sheets. International Journal of Smart and Nano Materials 1: 249-260.

36. Jiang HJ, Zhu LB, Moon KS, Wong CP (2007) The preparation of stable metal nanoparticles on carbon nanotubes whose surfaces were modified during production. Carbon 45: 655-661.

37. Yun H, Kim JD, Choi HC, Lee CW (2013) Antibacterial Activity of CNT-Ag and GO-Ag Nanocomposites Against Gram-negative and Gram-positive Bacteria. Bulletin of the Korean Chemical Society 34: 3261-3264

38. Yu L, Zhang Y, Zhang B, Liu J (2014) Enhanced antibacterial activity of silve nanoparticles/halloysite nanotubes/graphene nanocomposites with sandwichlike structure. Sci Rep 4: 4551.

39. Lara HH, Ayala-Nunez NV, Turrent LDI, Padilla CR (2010) Bactericidal effect of silver nanoparticles against multidrug-resistant bacteria. World Journal of Microbiology \& Biotechnology 26: 615-621.

40. Lukhele LP, Krause RWM, Mamba BB, Momba MNB (2010) Synthesis of silver impregnated carbon nanotubes and cyclodextrin polyurethanes for the disinfection of water. Water Sa 36: 433-436

41. Veerapandian M, Yun K, Subbiah R, Lee M (2014) Cytotoxicity of biosynthesized nanomaterials and functionalized nanomaterials use in therapy. In Nanobiomaterials: development and applications. Edited by Yi DK, Papaefthymiou GC. Boca Raton, FL: CRC Press, Taylaor \& Francis group 417-441

42. Agnihotri S, Mukherii S, Mukherji S (2014) Size-controlled silver nanoparticles synthesized over the range 5-100 nm using the same protocol and their antibacterial efficacy. RSC Advances: 3974-3983.

43. Li WR, Xie XB, Shi QS, Zeng HY, Ou-Yang YS, et al. (2010) Antibacterial activity and mechanism of silver nanoparticles on Escherichia coli. App Microbiol Biotechnol 85: 1115-1122.

44. Xu WP, Zhang LC, Li JP, Lu Y, et al. (2011) Facile synthesis of silver@ graphene oxide nanocomposites and their enhanced antibacterial properties. Journal of Materials Chemistry 21: 4593-4597.

45. Koivunen J, Heinonen-Tanski $\mathrm{H}$ (2005) Inactivation of enteric microorganism with chemical disinfectants, UV irradiation and combined chemical/UV treatments. Water Res 39: 1519-1526.

46. Lapenna D, Cuccurullo $F$ (1996) Hypochlorous acid and its pharmacological antagonism: an update picture. Gen Pharmacol 27: 1145-1147.

47. Thomas EL, Grisham MB, Jefferson MM (1983) Myeloperoxidase-dependent effect of amines on functions of isolated neutrophils. J Clin Invest 72: 441-454

48. Small DA, Chang W, Toghrol F, Bentley WE (2007) Toxicogenomic analysis of sodium hypochlorite antimicrobial mechanisms in Pseudomonas aeruginosa. Appl Microbiol Biotechnol 74: 176-185.

49. Estrela C, Estrela CR, Barbin EL, Spanó JC, Marchesan MA, et al. (2002) Mechanism of action of sodium hypochlorite. Braz Dent J 13: 113-117.

50. Bruch MK1 (2007) Toxicity and safety of topical sodium hypochlorite. Contrib Nephrol 154: 24-38.

51. Cabiscol E, Tamarit J, Ros J (2000) Oxidative stress in bacteria and protein damage by reactive oxygen species. Int Microbiol 3: 3-8.

52. Baldeck JD, Marquis RE (2008) Targets for hydrogen-peroxide-induced 
Citation: Dong X, Koo Y, Tang Y, Yun Y, Yang L (2015) Superior Antibacterial Activity of Photochemical Synthesized Ag-CNT Composites and their Synergistic Effects in Combination with other Antimicrobial Agents. J Nanomed Nanotechnol 6: 279. doi:10.4172/2157-7439.1000279

damage to suspension and biofilm cells of Streptococcus mutans. Can $\mathrm{J}$ Microbiol 54: 868-875.

53. Thomas EL, Milligan TW, Joyner RE, Jefferson MM (1994) Antibacterial activity of hydrogen peroxide and the lactoperoxidase-hydrogen peroxide-thiocyanate system against oral streptococci. Infect Immun 62: 529-535.

54. Breukink E, Wiedemann I, van Kraaij C, Kuipers OP, Sahl HG, et al. (1999) Use of the cell wall precursor lipid II by a pore-forming peptide antibiotic. Science 286: $2361-2364$

55. van Heusden HE, de Kruijff B, Breukink E (2002) Lipid II induces a transmembrane orientation of the pore-forming peptide lantibiotic nisin. Biochemistry 41: 12171-12178.
56. Hoover DG (1999) Microorganisms and their products in the preservation of foods. In The microbiological safety and quality of food. Edited by Lund BM Baird-Parker TC, Gould GW. Gaithersburg, Maryland: Aspen publishrs Inc: 251-276.

57. Pattanayaiying R, H-Kittikun A, Cutter CN (2014) Effect of lauric arginate, nisin $Z$, and a combination against several food-related bacteria. Int J Food Microbio 188: $135-146$

58. Chen SF, Ping Li J, Qian K, Xu WP, Lu Y, et al. (2010) Large Scale Photochemical Synthesis of M@TiO2 Nanocomposites (M = Ag, Pd, Au, Pt) and Their Optical Properties, CO Oxidation Performance, and Antibacteria Effect. Nano Res 3: 244-255. 